\title{
Quantification labour migration processes: systemization of the experience of foreign and domestic studies
}

\author{
Liudmyla Kalashnikova, and Viktoriia Chorna* \\ Petro Mohyla Black Sea National University, Department of Sociology, Ukraine
}

\begin{abstract}
The article made the attempt to systematize foreign and domestic research experiences on quantitative measurement of quality performance indicators work-migration processes. In particular, it analyses the possibility of harmonization of statistical accounting of labor migration, carried out by separate departmental systems to gather broad demographic information. As well as the features of the specialized and general sample surveys of the labour movement in the countries of ES and the post-soviet states. On the basis of the analysis of the necessity of the integration of economic, demographic and sociological approaches for full-scale analysis of the labour migration situation in the labour market. It is proved that sociological research work-migration processes more flexible, in comparison with the economic. And their use will allow to consider the impact on the adoption of the individual decisions on the labour movement of the whole complex of modern trends of development of society and economy. It is proposed to supplement recommendations A. Vorobyov, A. Grebenyuk, A. Topilin regarding the definition of the range of respondents, and social indicators included in the Toolkit of sample surveys of labour migration. The implementation of such methodological innovations will allow to solve the question of forecasting the dynamics work-migration processes.
\end{abstract}

\section{Introduction}

The regulation of labour migration processes, both external and internal, is one of the priorities of state institutions considering the need to control employment, income, living standards, and social well-being of society. Timely and reliable information is needed to assess the labour migration process. Developing strategies, forecasting dynamics and preventing negative effects are encompassed in this study.

The methodology for the study of labour migration involves the definition of the principles, structure, logic, forms, methods and means of scientific knowledge of the investigated phenomenon. The main problem of taking into account socio-economic indicators of movement of labour is the procedure for identifying a migrant worker. The definition of labour migration, set out in laws and other legal documents, should be clear, unambiguous and suitable for developing procedures for its quantitative analysis. However, in practice, representatives of state institutions do not always turn to sound scientific concepts. Therefore, the existing systems of statistical accounting differ not only in different countries, but even between individual departments of one state, since the latter can carry out accounting using absolutely different methods, choosing them depending on the specific tasks and functions of particular organizations. This state of affairs leads to a low level of data comparability or even complete absence thereof.

The difficulty of mainstreaming migrations, in comparison with vital statistics, is that you can be born and die only once, whereas in various kinds of labour movements a person can be involved many times. Thus, a labour migration statistics operates with events, facts of check-in/check-out activities, but not with quantitative indicators of the number of labour migrants, which significantly reduces the quality of mainstreaming, primarily due to the increase in the number of events that are recorded in comparison with the birth or death statistics. Another circumstance that causes problems in the collection of empirical information regarding labour migration is the presence of its irregular form, which is practically cannot be measured directly, and, accordingly, it is very difficult and sometimes impossible to determine its size and characteristics.

Labour migration in all countries, having mainly elusive nature, is one of the most difficult mainstreamed socio-economic phenomenon. The problem of absence of correct statistical information about various kinds of labour movement is felt acutely for both regions/donor countries and recipient countries. Consequently, nowadays in the context of globalization, the need for establishing and development of directions in statistical activity, related with the possibility of their mainstreaming, is actualized by labour flows increasing and also the emergence of new forms of labour movement.

The purpose of the research is to systematize the experience in quantitative studies of the dynamics trade magazine processes, as well as the conduct of specialized and General sample surveys of the labour movement in the countries of the European Union and post-Soviet 
States, for the development of methodological innovations, the implementation of which will optimize the social mechanisms of the state policy of regulation of labour migration.

The main source of information on migrations, including labour migration, is the state statistics, which provides current records of movements and a population census. Statistical study of labour migration processes should be based on the results of statistical monitoring of the labour activity of the population, which allow to estimate the determinants of labour migration formation, to identify significant/insignificant, clear/latent ones among them. Statistical accounting of international labour migration is a complex procedure that covers events registered simultaneously in two regions/countries (donor and recipient). The UN uses the model of accounting for international flows of migrants, which makes it possible to identify the links between leaving one country and arriving in another one. Of course, using such a model, it is necessary to take into consideration some theoretical assumptions that were made to construct it [4]. In particular, information support for the study of labour migration processes is defined as a scientifically based activity of stakeholders on collecting, fixing, processing, accumulating, storing and using information, messages and any other data in order to analyse labour migration processes, as well as develop state migration policy [5]. The system of information support for the analysis of labour migration includes official statistical data (current records, censuses and population registers, statistics on the crossing of state borders, etc.), as well as information received during specialized research studies conducted by academic institutions and other specialized sample survey organizations.

\section{Brief literature review}

A significant increase of irregular migration, in particular, labour migration, is defined as one of the most significant trends in world migration flows. According to the Organization for Economic Cooperation and Development, in 2017258 million people were forced to leave the countries where they were born and lived, and more than 5 million of them received a permanent residence in the EU countries. On results of the year 2017, the total number of migrants from the countries of the Middle East and North America was 1.413 million people in Germany per 1 thousand of the permanent population, in France -0.402 million, in Italy -0.355 million, in Sweden -0.328 million, in Latvia -0.234 million [1]. The number of migrants arriving from Central America (Mexico, Guatemala, Honduras, El Salvador) in the US and Canada for the period 2017-2018 increased almost 5 times [2]. A number of negative effects of increased labour flows (increased population pressure on workers in the domestic market, reduced efficiency and productivity, increased pressure on social infrastructure, the lack of opportunity for reinvestment of earned money into the economy of a region/country of entry, etc.) led to an immediate reaction of the recipient countries in the form of widespread public protests, which the press dubbed "suicidal hospitality" [3].

\section{Results and discussion}

In Ukraine, for instance, as in most post-Soviet countries, statistical information on labour migration processes is provided by specialists from the Ministry of Internal Affairs, the State Committee on Nationalities and Religions, the State Border Service, the State Migration Service, the Department of Labour Statistics, the State Employment Centre of the Ministry of Labour and Social Affairs, the Ministry of Foreign Affairs, the Ministry of Education and Science, etc. Procedures for collecting data on labour is regulated by internal orders and directives of these agencies. Despite the recommendations of the UN on the need to create departments in certain ministries responsible for collecting such statistical information, in Ukraine none of the departments, with the exception of the State Statistics Committee, has such units.

State statistical agencies carry out the current registration of migration, using information on registration (in the past - residence registration/deletion) of citizens by processing statistical records of the arrival/departure address lists filled in at the passport office. The following documents for introducing registration act as the legislative framework: The Law "The International Labour Migration" dated November 5, 2015 [6], The Presidential Decree "On Implementation of Civil Registration as an Integrating System of Population Registration" [7], The Resolution of the Cabinet of Ministers "On approval of the Interim Statute for the Registration of Individuals at their Place of Residence" dated January 16, 2003 [8] and the Law "On Freedom of Movement and Free Choice of Place of Residence" of January 9, 2004 [9]. The main difference of the current accounting system is its constancy, which ensures the continuity of monitoring of the existing changes in labour migration processes. The unified methodology and broad regional coverage of data collection provides an opportunity to make inter-regional comparisons and to obtain fairly complete, objective information within the country. Recently, some significant changes have occurred in the current migration registration system related to the cancellation of residence permit and the introduction of registration, as well as the introduction of a new primary document for migration registration (lists for statistical data on arrival/departure) and a new data processing program in 1995. Such innovations, according to statistics, provide an opportunity to improve the accuracy and detail of information on the movements of labour.

The main source of data on the flow of international migrant workers is the " 1 -IM" statistical record form "Report on the number of citizens who are temporarily employed abroad", which was introduced in accordance with the order of the Ministry of Statistics (now the State Statistics Committee) dated May 30, 1996. Commercial offices, agencies and other organizations engaged in employment in other countries provide information on labour migrants who used their services during the year. 
This source of official statistics covers only a few specific, in comparison to the overall level of the labour migration cohorts, participants who were employed abroad using the services of official intermediaries. Therefore it cannot serve as the main base for analyzing labour relocations, but is only an additional source of information [10].

Another important source of data on external and internal labour migration is the statistical reporting form of rural settlements "1-village". This form is not a part of the current population statistics, it is developed every five years and is filled for each rural population centre of Ukraine. The main information that can be obtained from this source is the number of villagers who are employed outside of it (in cities and urban-type settlements of the same region, outside the region or abroad).

The population census is the largest event of statistical population registration. As the named method of registration of migrations has little credibility, the requirements for the development of a population census program have been significantly increased, in particular, to include questions that should ensure the collection of statistics on labour migration. The main advantage of this source of information is that information is collected nationwide. It is also of great significance that the regular frequency of censuses usually takes place once every ten years. However, some authors note that such a periodicity of censuses makes it impossible to investigate the evolution of labour migration flows [11], others point to the inability of censuses to reflect rapid changes in labour migration [12]. In addition, the questions asked during the census in different countries differ significantly, making it difficult to estimate labour migration. It should be noted that in fact external labour migration excludes an individual from the census, therefore, information about the relocation is obtained according to their family members. In addition, censuses cannot provide complete objective information about the motives, circumstances, and consequences of labour migration, since they are conducted on a standardized questionnaire.

Population registers are considered the most reliable systems for collecting demographic information (including migration information). They are a database that is constantly changing and being updated thanks to current records of births, deaths, marriages/divorces, as well as changes in place of residence. Population registers provide information on each resettlement in a country for a specific period of time. In addition, this source of information provides the ability to obtain information about temporary migrations. Such data is not flawed, but more reliable than the data obtained from other sources. In some countries, for example in the Netherlands, the work of registers is organized so competently that the need for censuses is no longer relevant [13]. However, the registers have a number of drawbacks, namely, they can contain detailed information about migrants, but no information about the motivation of labour movement.

In the statistics of the countries of the post-Soviet space today there are no population registers, but there is an active discussion regarding their implementation. Creating such a source of information is facing a number of challenges. On the one hand, the legislative base of states does not contain documents that would oblige the population to provide information to the registers and to regulate an exact type of information, nor does there exist standards for using such information and guarantees of confidentiality. Besides legal, there are also material obstacles related to the need to acquire and maintain modern high-tech equipment, software, reliable communication systems, etc.

Speaking of border statistics, we note that it keeps records of border crossing facts, but not the number of migrants, including labour migrants. It is necessary to use the data obtained from this source with specified reservations, especially when it comes to determining the purpose of the trip, since it is noted depending on the type of visa received or according to what a migrant said. As a matter of fact, it is clear that such information is not always complete and objective.

Sample surveys that have a more flexible data collection tool can supplement the information on the number of migrant workers provided by various kinds of state institutions, organizations and agencies. All conducted sample surveys can roughly be divided into two types: specialized, dedicated to a deep analysis of labour migration itself, and general surveys consisting of various thematic clusters of issues, which may include a set of issues related to migration, including labour migration.

The development of sampling methods for the study of labour migration in a number of developed countries was largely due to the absence of an institution for civil registration at their place of permanent residence. A striking example is the experience of statistical registration of labour migrants in the USA and the UK. An alternative method is using the Central Population Register (for example, in Norway, Austria, Belgium, etc.), in which, as a rule, data on foreigners who are present on the territory of the state for a certain period of time, are recorded in addition to data on residents of a country [14]. It should be emphasized that sample study is widely used by both donor countries and recipient countries. The example of the main forms of such observations include studies focused on labour force - LFS (Labour Force Survey) (EU countries, Philippines, Canada, etc.), passenger traffic - IPS (International Passenger Survey) (United Kingdom, Mexico, etc.), population of the country (including demographic) - CPS (Current Population Survey) (USA, Mexico, etc.), households IHS (Integrated Household Survey) (Bulgaria, United Kingdom), vocational training and qualification of workers - FQP (The Formation Qualification Professionnelle Survey) (France, Mexico, etc.), income and expenditure of families (household budgets) - FIES (Family Income and Expenditure s Survey) (Philippines, Poland, etc.), living standards - LSMS (Living Standards Measurement Study) (Tajikistan, Azerbaijan, etc.), as well as longitudinal surveys - LSI (Longitudinal Survey of Immigrants) (Canada, UK) [15].

First of all, we are interested in the experience of host countries that use sample surveys to statistically estimate the number of foreign citizens in their territory, in particular the UK and the USA. The tools of such surveys often contain questions about the interaction of the respondent with private employment agencies, since their 
studying is important in identifying foreign workers employment mechanisms. Often they include blocks focused on commuting (Travel to work) and educationalrelated (Foreign Qualifications) migration [16]. In the UK, the National Statistical Office conducts a sample survey of international passenger traffic (IPS) at air- and seaports, at the border points of the English Channel Eurotunnel [15].

The vast experience of using selective research for collecting data on migrant workers has been gained in the USA. The reason for the wide application of this type of research is the absence of a residence registration. An alternative are special administrative sources of data on migration flows, which are targeted used only for international migration registration. Among the measured social indicators, those are of particular interest, which are related to the study of the mechanism of employment, and also aimed at identifying second-generation migrants through questions about the place of birth of parents [13].

No less interesting is the experience of researchers with respect to estimating the number of labour migrants in France, where, since 1950, labour force LFS surveys have been conducted (Labour Force Survey). This kind of research allows you to collect a database on the integration of migrants, both the first and next generations [14]. In Germany they conduct studies similar to LFS, which allows us to estimate the size and composition of both internal and external labour migrants. In Canada, a longitudinal study of labour force LSIC (Longitudinal Survey of Immigrants to Canada) is conducted, the methodology of which differs from that adopted in the EU. Its main purpose is to obtain information on how well immigrants integrate into local society and what factors contribute to or hinder this [13]. Particular attention should be paid to experience in conducting labour force surveys in the Philippines, where the national statistical agency through a number of different surveys of households collects information about citizens migrating abroad [14].

The procedure of collecting statistical information by means of forms filled in at the border is very complicated and cumbersome due to the growth of international migration flows. Only in Bulgaria, following the example of Great Britain, there is a special selective survey conducted to study international migration on the basis of border crossing facts. Poland, which uses census forms for all people crossing the border, abandoned this method of measuring migrations same way as Italy and Portugal [17].

Trying to draw parallels between EU countries and post-Soviet states regarding the methodology of researching labour migration, S. Ryazantsev noted that full-scale studies of external labour migration are conducted in Russia, Belarus, Kazakhstan and Ukraine, less regularly and massively in Moldova, Tajikistan, Azerbaijan and Uzbekistan [13]. The obtained data are systematized and actively used by the International Statistical Committee of the CIS [18]. There are some nuances of conducting such kind of surveys in different countries. Thus, according to the methodology of household surveys in Armenia, the number of labour emigrants includes family members who went to work in another country and have been absent for more than three months, while in Kazakhstan this period is extended to six months, in Belarus, Russia and Ukraine - to one year. And in Kyrgyzstan and Moldova, labour emigrants are considered to be all members of households who have left for work abroad, regardless of the period of their absence. No less informative are thematic and modular surveys aimed at studying the characteristics of internal and external labour migration, opportunities and ways of using migrant labour, the impact of migration and remittances on household welfare/poverty, etc. [19].

Systematizing information on means and methods for quantifying labour-migration processes, we note that most countries estimate labour emigration on the basis of sample surveys, while administrative systems are used to measure labour immigration, which are related to issuing work permits. We have summarized the experience of different countries that actively accept labour migrants or have a high mobility of the local population. It shows that the methodology for conducting such selective research is almost the same, except for the time and frequency of the survey, as well as the volume and content of the questions. The main reason for this is the coordination of the organization and conduction of sample surveys of employment of the population, labour migration in particular, by the International Labour Organization, the International Organization for Migration at the UN, the Organization for Economic Cooperation and Development, etc. The last of them conducts the most extensive studies on migration in general, and labour migration in particular. The methodology of these studies is based on the fact that population of labour migrants staying in the country can be assessed by appealing to data on the number of foreigners with valid work permits [20]. However, for many migrants, the presence of such a permit is not a guarantee of employment, therefore, it is necessary to take into account data on the number of foreigners who work in the recipient region or country. Among the main indicators that digitalise labour migration trends are the following: the number and proportion of the population born by migrants; the proportion of foreigners in the total population of the country; the number of foreign workers, including seasonal (temporary); the number and proportion of the foreign population and the population born abroad in the labour force; statistics of the legalization of illegal migrants by their countries of origin [13].

The variety of definitions and approaches to recording labour migration leads to significant statistical discrepancies in the values of labour migrant flows. Consequently, work on the improvement of statistics should be carried out in close contact with the services and departments that are responsible for managing labour migration processes. In particular, the development of the methodology for registration of external labour migration was provided by the project "Labour Statistics Improving in the CIS Region", which was implemented in 20142016 by Statistical Committee of the CIS countries in cooperation with the World Bank [19].

The question of internal labour migration remains open, which has not been studied properly for a long period of time. The situation has become particularly 
difficult given the reduction in the working-age population and the need for a more complete use of labour reserves. That is why it is extremely important to study internal labour movements together with the international migration of labour. Partially, the problem of studying internal labour migration is being solved within the framework of selective research of the population on employment problems, as they provide an opportunity to establish interregional migration links, demographic characteristics of labour migrants, and describe the sectoral structure of the sphere of their labour use. The balance in the labour market can be assessed by operating with data on available vacancies in the regional labour market and the volume of foreigners attracting.

A. Vorobiev, A. Grebenyuk, A. Topilin, summarizing the experience of conducting sample surveys of labour migration, made a number of recommendations:

1. Identifying the circle of respondents:

- members of household entrepreneurs (legal entities or individuals) who use migrant workers as employees in their enterprises or organizations;

- the head or members of households who employ labour migrants in their households (housekeeping, care and upbringing of children, care for the sick, disabled, retired people, residential security, refurbishing housing estates, landscaping, etc.);

- members of households of migrant workers who temporarily live in the territory of the recipient country; - the head or members of households that include international migrant workers;

- the head or members of households that include internal labour migrants;

- the head or members of households with labourmigration intentions [14].

In our opinion, the proposed list should be supplemented with such groups of respondents as: external/internal labour migrants; labour migrants with previous experience in labour relocation and who returned to their permanent place of residence in the region/donor country; employees of intermediary companies engaged in the employment of migrant workers abroad/within the country; household members in the regions/countries of arrival; experts on labour migration (leading experts of the Ministry of Economic Development and Trade, Ministry of Social Policy, National Bank of Ukraine, United Nations Development Program (UNDP), International Labour Organization (ILO), National Institute of Demography and Social Research, etc.); employers.

2. Determination of the main blocks of questions included in the research tool:

- information about respondents (gender, age, place of residence, citizenship, level of education, place of education, profession, knowledge of the language of the country of arrival, place of birth of parents);

- job characteristics (type of economic activity, qualification, position, duration of work, professional experience, form of recruitment and wage, the nature and complexity of the work performed);

- job search (channels of employment, intermediaries when there are, the duration of the job search or organization of their own business);
- remittances (methods of keeping in touch with family, remittance flow, transmission channels, frequency, currency);

- causes of labour migration;

- labour intentions (motivations of movement, preferences regarding future employment, intentions to enhance education, qualifications, career growth) [14].

We find it appropriate to supplement the above list of social indicators measuring the dynamics of labour migration in accordance with the proposed groups of respondents with such indicators as:

- obstacles to adaptation in the region/country of arrival; - plans for returning to a permanent place of residence, awareness of the activities of organizations, companies or ministries that provide information or assistance (of any kind) to people who plan to find a new job in the region/country of recipient;

- assessment of the effectiveness of organizations, companies or ministries providing assistance to migrant workers;

- the frequency and reasons for contacting the above organizations;

- the activity of migration networks, the presence of a circle of acquaintances labour migrants, the nature of the relationship with them;

- labour migration management mechanisms, assessment of their effectiveness;

- legalization of employment of migrant workers;

- the effectiveness of migration policies at the level of the state, region, etc.

\section{Conclusions}

In national studies, economic and socio-demographic approaches to the study of labour migration of the population prevail. They are characterized by limitations regarding the possibility of conducting statistical observations. Therefore, the methodology, theory and instrumental possibilities of sociological science, which are of interdisciplinary nature, are relevant for a comprehensive study of labour migration. In contrast to economists and demographers who use aggregated indicators of national statistics, sociologists rely mainly on sample survey data. Sociological research methods, including household sampling surveys, are based on descriptive analysis. And sociological models of labour migrant behaviour are more flexible than mathematical ones, which are used by economists. Even in spite of the fact that it is sociological models that are most often subject to empirical verification, they are more effective. The use of sociology in the study of labour migration processes allows to take into account the impact on the individual's decision to move a whole complex of modern trends in the development of society and the economy: unemployment growth and the impossibility of a steady increase in employment; growing inequality between countries; increasing the role of intellectual capital; reduction of opportunities for creative realization; needs of recognition from the environment; loss of a sense of individuality and the usefulness of work in connection with total computerization, etc. 
Combining economic, demographic and sociological approaches will significantly enrich and complement both the analysis of labour migration and the analysis of the situation on the labour market. It also provides an opportunity to consider its elements as the result of objective and subjective aspects of the work of individuals, their internal and external stimuli and motives. Using such a synthesis, it is possible to segment labour migration flows, which in the future will contribute to the development of more effective state programs for regulating the movement of labour, attracting certain categories of labour migrants, programs for their adaptation and vocational guidance.

Summing up, we note that solving the methodology problems for conducting specialized sample surveys at the state level will help clarify issues of fundamental importance for users of this kind of data. The leading users are institutional structures (legislative and executive bodies) that are responsible for developing and implementing state migration policy. In order to expand the range of statistical information on labour migration, it is necessary to develop existing methods and forms of statistical observation. In addition, it's appropriate to supplement their organization with new means, drawing upon the leading experience of foreign countries in the study of this kind of problems. It is desirable to study labour migration as a whole as well as conduct deep, fullscale studies of its individual forms, in particular internal periodic circular migration, especially in the satellite regions of large cities, regional and industrial centres. Information on circular migration is necessary for the assessment and organization of transport flows, the effectiveness of the social sphere. The source of information on the integration of migrant workers, the effectiveness of the existing socio-cultural infrastructure and educational system, the satisfaction of career opportunities can be specialized surveys of their professional training and qualifications.

Thus, improving the range of means for obtaining data about labour migration, including population censuses, citizen registers, sample surveys of labour migrants themselves, their family members and others who are in one way or another involved in the movement of labour, is very important. In this way it is possible to obtain more complete, reliable information capable of filling in the gaps in the traditional types of statistical observation. First of all, by counting and expanding the list of social indicators that can be measured by sociological methods. That, in turn, will provide an opportunity to solve the issue of forecasting the dynamics of labour-migration processes and to optimize the social mechanisms of the state policy of regulating labour migration.

\section{References}

1. International Migration Outlook 2018 (OECD Publishing, Paris, 2018). doi:10.1787/migr_outlook2018-en

2. E. Koroleva, Perekryt' granicu: Tramp prigrozil Meksike (Block border: trump has threatened Mexico)

(Gazeta.ru,

2018), https://www.gazeta.ru/politics/2018/10/18_a_12026 659.shtml. Accessed 18 Oct 2018

3. A. Khokhlov, Samoubijstvennoe gostepriimstvo. Evropa vpuskaet v svoj ujutnyj dom vojnu (Suicidal hospitality. Europe lets in a house war) (Evening Moscow, 2015), https://vm.ru/news/297560.html. Accessed 16 Sep 2015

4. Socialno-ekonomichne stanovyshhe regioniv Ukrayiny (The socio-economic situation of the regions of Ukraine), http://www.ukrstat.gov.ua. Accessed 5 Jan 2019

5. N. Polishhuk, Zovnishnya trudova migraciya $\mathrm{v}$ Ukrayiny - regionalna struktura (External labour migration in Ukraine - a regional structure) (Information-analytical center Info-Light, 2013), http://infolight.org.ua/maps/zovnishnya-trudovamigraciya-v-ukrayini-regionalna-struktura. Accessed 15 May 2013

6. Pro zovnishnyu trudovu migraciyu (On external labour migration) (The Law of Ukraine, 2015), http://zakon4.rada.gov.ua/laws/show/761-19. Accessed 5 Dec 2019

7. Pro zaprovadzhennya reyestraciyi gromadyan yak povidomlyayuchoyi systemy obliku naselennya (On introduction of registration of citizens as a reporting system of population accounts) (The Decree of The President Of Ukraine, 2002), http://zakon3.rada.gov.ua/laws/show/12/2002. Accessed 6 Ap 2011

8. Pro zatverdzhennya Tymchasovogo Poryadku reyestraciyi fizychnyx osib za miscem prozhyvannya (About approval of the Temporary Procedure for the registration of natural persons at the place of residence) (The Resolution of The Cabinet Of Ministers Of Ukraine, 2003), https://zakon.rada.gov.ua/laws/show/35-2003$\%$ D0\%BF. Accessed 11 May 2006

9. Pro svobodu peresuvannya ta vilnyj vybir miscya prozhyvannya v Ukrayini (On freedom of movement and free choice residence in Ukraine) (The Law of Ukraine,

http://zakon4.rada.gov.ua/laws/show/1382-15. Accessed 12 December 2019

10. Zvit shhodo metodologiyi, organizaciyi provedennya ta rezultativ modulnogo vybirkovogo obstezhennya $\mathrm{z}$ pytan trudovoyi migraciyi v Ukrayini. Mizhnarodna organizaciya praci. Grupa texnichnoyi pidtrymky z pytan gidnoyi praci ta Byuro MOP dlya krayin Centralnoyi ta Sxidnoyi Yevropy (The report on the methodology, organization and results of a modular sample survey on labour migration in Ukraine. The international labour organization. The technical support group on decent work and the Bureau of the International labour organization for the countries of Central and Eastern Europe) (Budapest, The international labour organization, 2013), http://www.ilo.org/wcmsp5/groups/public/@europe/ @ro-geneva/@srobudapest/documents/publication/wcms_244746.pdf. Accessed 27 May 2014 
11. E.M. Libanova, O.G. Osaulenko, N.S. Vlasenko, Pershyj Vseukrayinskyj perepys naselennya: istorychni, metodologichni, socialni, ekonomichni, etnichni aspekty (The first all-ukrainian census: of the historical, methodological, social, economic, ethnic aspects), ed. by I.F. Kuras (Kiev, 2004), p. 12

12. O. Malynovska (ed.), Migracijni procesy v Ukrayini: suchasnyj stan i perspektyvy (Migration processes in Ukraine: current state and prospects). (Kiev, 2016)

13. S.V. Ryazantsev, Trudovaja migracija $v$ stranah SNG i Baltii: tendencii, posledstvija, regulirovanie (Labor migration in CIS and Baltic countries: trends, consequences, regulation). (Formula Prava, Moscow, 2007), pp. 36-51

14. O.D. Vorobyova, A.A. Grebenyuk, A.V. Topilin, Problemy informacionnogo obespechenija prognozirovanija trudovoj migracii $\mathrm{V}$ Rossii (Problems of information support of forecasting labour migration in Russia). Problems of forecasting 4, 52-58 (2014)

15. State of World Population-2011 (UNFPA, New York, 2012), pp. $20-32$,

https:/www.unfpa.org/sites/default/files/pubpdf/RU-SWOP2011.pdf. Accessed 15 Dec 2012

16. C. Ozden, International Migration, Remittances and the Brain Drain (The International Bank for Reconstruction and Development, Washington, 2006), p. 24

17. Labour Force Survey (User Guide, LFS Questionnaire, Office for National Statistics, 2015), http://webarchive.nationalarchives.gov.uk/20160105 160709/http:/www.ons.gov.uk/ons/guide$\mathrm{method} / \mathrm{method}$-quality/specific/labourmarket/labour-market-statistics/index.html. Accessed 2 August 2015

18. International statistical committee of the CIS (2018), http://www.cisstat.com

19. Aktualnye problemy migracionnoj statistiki na prostranstve SNG (po materialam Statkomiteta SNG) (Actual problems of migration statistics in the CIS) (The Internet portal of the Commonwealth of independent States, 2018), https://ecis.info/cooperation/3049/78437/. Accessed 21 Mar 2020

20. International migration statistics. A practical guide for countries of Eastern Europe and Central Asia (UN, Geneva, 2011), p. 50, https://www.unece.org/fileadmin/DAM/stats/publica tions/RUS_International_Migration_Statistics_Pract ical_Guide.pdf. Accessē 21 Mar 2020 